\title{
PENGARUH PEMBERIAN JUS KACANG HIJAU DAN MADU TERHADAP KADAR HEMOGLOBIN PADA IBU HAMIL
}

\author{
SRI WULAN ${ }^{1}$, MUNIAR VINDRALIA² \\ 1,2 Institut Kesehatan MEDISTRA Lubuk Pakam \\ Jl. Sudirman No 38 Lubuk Pakam Kab.Deli Serdang, Sumatera Utara. \\ e-mail : wulan194@gmail.com
}

DOI $10.35451 /$ jkf.v3i2.610

\begin{abstract}
Anemia is a problem that often accompanies pregnancy. The most common anemia during pregnancy is nutritional anemia caused by iron deficiency. Pregnant women were considered to have anemia, if their hemoglobin $(\mathrm{Hb})$ level $<11 \mathrm{gr} / \mathrm{dL}$. Anemia could be worst the birth process. Anemia could be overcome with pharmacological and non pharmacological treatments, one of the non pharmacological treatments for the prevention of anemia in pregnant women is to consume green bean juice and honey because green bean juice and honey contain iron and vitamins which can increase the hemoglobin level. This study aims to determine the effect of giving green bean juice and honey on hemoglobin levels in pregnant women. The research method used was quasi-experimental (Quasi Experiment) with one group pre and post test design. The study population was all pregnant women who performed ANC at the Maiharti West Range Midwife clinic. The sampling technique used purposive sampling with the results of 19 pregnant women. The results showed that from using the Paired Sample T-Test analysis of giving green bean juice and honey to increase hemoglobin levels in pregnant women where the $p 0,00<a=0,05$. It could be concluded that the administration of green bean juice and honey is effective in increasing hemoglobin level
\end{abstract}

Keywords : Pregnant Women, Mung Beans, Honey

\section{Pendahuluan}

Menurut World Health

Organization (WHO) bahwa kejadian anemia pada kehamilan antara $20 \%$ hingga $89 \%$ dengan ketentuan $\mathrm{Hb} 11$ $\mathrm{gr} / \mathrm{dl}$. Kejadian anemia di Indonesia merupakan masalah yang cukup tinggi. Hoo Swie Tjiong mengatakan bahwa angka anemia yang disebabkan karena kehamilan sebesar $3,8 \%$ terjadi pada trimester ke 1, 13,6\% trimester ke 2 dan $24,8 \%$ di trimester ke 3 (Manuaba, 2012).

Anemia sendiri merupakan hal yang berbahaya bagi ibu yang sedang hamil, penyakit ini sering kali datang pada masa kehamilan karena pada saat hamil ibu membutuhkan unsur makanan dengan jumlah yang banyak, misalnya folic acid, protein dan zat besi. Jika kebutuhan ini tidak tercukupi, maka ibu hamil kemungkinan mengalami anemia dan seringkali ibu lalai dalam mengkonsumsi zat-zat tersebut (Lamadhah, 2016).

Anemia pada kehamilan dapat menyebabkan daya tahan tubuh menurun yang dapat menyebabkan kematian pada janin dalam kendungan, BBLR, abortus dan cacat bawaan pada persalinan juga dapat menyebabkan inersia uteri, ibu menjadi lemas 
sehingga menimbulkan partus lama, sedangkan pada saat msa nifas dapat terjadi perdarahan dan pada keadaan ini tubuh tidak dapat mentoleransi seperti ibu yang sehat yang tidak menderita anemia. Hal inilah yang dapat menyebabkan morbiditas dan mortalitas serta kematian perinatal lebih tinggi (Saifuddin, 2015).

Hasil Riset Kesehatan Dasar tahun 2018, prevalensi kejadian anemia pada kehamilan di Indonesia sebesar $37,1 \%$ pada tahun 2018 Presentase ini mengalami peningkatan pada tahun 2018 yang mencapai prensentase sebesar $48,9 \%$. Walaupun pemerintah sudah menjelaskan tentang program penanggulangan anemia pada ibu yang hamil yaitu dengan menganjurkan untuk mengkonsumsi tablet Fe sebanyak 90 tablet ke semua ibu hamil selama masa periode kehamilan, ini bertujuan untuk menurunkan angka kejadian anemia kepada ibu hamil, tetapi meskipun demikian kejadian anemia masih tergolong tinggi karena masih banyak ibu hamil yang tidak patuh dalam mengkonsumsi zat besi (Kementrian Kesehatan RI, 2017).

Pencegahan anemia pada ibu hamil dapat dilakukan dengan berbagai cara yaitu dengan cara farmakologi dan non farmakologi. Adapun cara non farmakologi adalah dengan mengkonsumsi kacang hijau dan madu. Kacang hijau selain mengandung zat besi, zat seng dan vitamin $C$ yang fungsinya sangat berperan didalam penanganan anemia zat besi, kacang hijau juga memiliki kandungan vitamin A sekitar $7 \mathrm{mcg}$ dalam setengah cangkirnya (Astawan, 2009). Kekurangan vitamin A di dalam tubuh dapat memperburuk anemia defisiensi besi, mengkonsumsi suplementasi vitamin A dapat menguntungkan bagi penderita anemia karena Vitamin A sangat berfungsi di dalam tubuh, misalnya untuk pertumbuhan dan deferensiasi sel progenitoreritrosit, kekebalan tubuh terhadap penyakit infeksi dan merupakan mobilisasi cadangan zat besi pada seluruh jaringan tubuh. Interaksi vitamin A dan zat besi bersiat sinergis (Amalia, 2016).

Kacang hijau dan madu yang mengandung zat besi yang berfungsi membantu dalam melakukan sirkulasi oksigen darah. Vitamin A dan C nya yang sama-sama berfungsi sebagai anti oksidan yang dapat melindungi tubuh dan otak dari racun dan populasi. Vitamin C membantu penyerapat zat besi untuk proses sistem kekebalan tubuh. Selain itu, kacang hijau juga memiliki kandungan asam folat dan vitamin B12 yang berfungsi untuk pembentukan sel darah baru yang dapat meningkatkan hemoglobin (Sugianto, 2013).

$$
\text { Kacang hijau juga banyak }
$$

bermanfaat bagi kehamilan seperti kandungan asam folat pada kacang hijau yang cukup tinggi dapat memberikan perlindungan pada bayi sehingga terhindar dari BBLR ataupun kelahiran prematur serta dapat membantu mencegah terjadinya cacat pada tabung saraf, serta kelainan serius pada otak dan sumsum tulang belakang. Vitamin $\mathrm{K}$ yang terdapat dalam kacang hijau juga berperan dalam mempertahankan kondisi tulang agar tetap kuat bagi ibu dan janin dalam kandungan. Gangguan pencernaan pada ibu hamil juga dapat diatasi karena kacang hijau kaya akan kandungan serat dan membantu masalah pencernaan seperti sembelit dan menjaga kesehatan saluran pencernaan (Maryana, 2015).

Berdasarkan penelitian Amirul Amalia (2016) terjadi peningkatan kadar hemoglobin pada remaja putri yaitu $1 \mathrm{gr} / \mathrm{dl}$ stelah diberikan jus kacang kacang hijau sebanyak $500 \mathrm{ml}$ dan diberikan 2 kali dalam sehari yaitu pagi 
dan siang hari selama 7 hari. Hal ini disebabkan karena kacang hijau mengandung kadar zat besi tinggi sebesar 7,5 mg per 100 gr serta zat gizi lain seperti asam folat, thilamin, protein, asam pentonetat dan mineral berupa kalium, magnesium, fosfor dan tembaga yang dapat membantu pembentukan sel-sel darah pada sumsum tulang belakang.

Berdasarkan hasil penelitian Retnorini, Widatiningsih \& Masini (2017) tentang pengaruh pemberian tablet FE dan sari kacang hijau terhadap kadar HB pada ibu hamil diperoleh bahwa rata-rata kadar HB ibu hamil sebelum intervensi 9,8 dan setelah intervensi 10,78 disarankan kepada ibu hamil untuk dapat mengkonsumsi tablet $\mathrm{Fe}$ dan sari kacang hijau karena efektif untuk meningkatkan kadar $\mathrm{HB}$ pada ibu hamil.

Berdasarkan hasil penelitian yang dilakukan Nur Islamiyah (2017) sesudah pemberian intervensi madu selama 7 hari berturut-turut diperoleh $p$ value $0,002<0,05$, sehingga dapat disimpulkan bahwa terdapat peningkatan kada hemoglobin sesudah dilakukannya intervensi pemberian madu. Hal ini dikarenakan madu memiliki kandungan mineral dalam madu diantaranya belerang (S), kalsium (Ca), tembaga ( $\mathrm{Cu})$, mangan $(\mathrm{Mn})$, besi $(\mathrm{Fe})$, fosfor $(\mathrm{P})$, klor $(\mathrm{Cl})$, kalium (K), magnesium $(\mathrm{Mg})$, iodium (I), seng ( $\mathrm{Z}$ ) dan aluminium (Al) sedangkan postasium merupakan menireal utama pada madu, disamping itu madu pun mengandung vitamin diantaranya vitamin E, itamin C serta vitamin B1, B6 dan asam folat (Faisal M.Sakri. 2015)

\section{Berdasarkan}

survey

pendahuluan yang telah dilakukan di Klinik Bidan Maiharti Kisaran Barat ibu hamil yang melakukan kunjungan Antenatal Care(ANC) ada 24 ibu hamil dan masih melakukan kunjungan ulang. Dan terdapat ibu hamil yang mengalami anemia pada trimester pertama sebanyak 6 orang, trimester kedua ada 13 orang dan trimester ketiga ada 5 orang. Pada saat peneliti melakukan survey pendahuluan, sebanyak 3 orang ibu hamil yang berkunjung dan 2 diantaranya mengalami anemia dan mereka tidak tahu bahwa kacang hijau dan madu dapat diguankan untuk sebagai alternative tradisional untuk masalah anemia.

diatas peneliti tertarik untuk melakukan penelitian mengenai pengaruh jus kacang hijau dan madu teradap kadar hemoglobin ibu hamil.

\section{METODE}

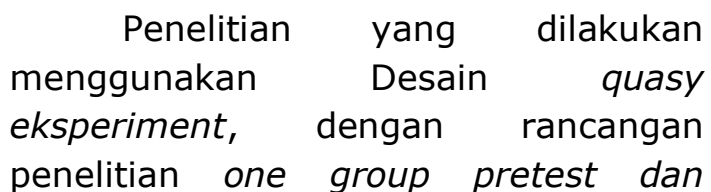
posttest. Penelitian ini diawali dengan pengukuran kadar hemoglobin praintervensi pada responden, kemudian diberikan intervensi dalam jangka waktu 7 hari dan diakhiri dengan pengukuran kadar hemoglobin pasca intervensi pada responden. Penelitian ini dilakukan di Klinik Bidan Maiharti Kelurahan Sidomukti Kecamatan Kisaran Barat. Sampel dalam penelitian ini adalah seluruh ibu hamil yang melakukan ANC di klinik Bidan Maiharti sebanyak 19 orang. Penelitian ini menggunakan lembar Observasi dengan menggunakan uji statistic paired $t$ test yaitu dengan tingkat kepercayaan $95 \%(a=0,05)$.

\section{HASIL}

Tabel 1. Distribusi Frekuensi Karakteristik Responden Berdasarkan Usia, Pekerjaan dan Pendidikan Pada Ibu Hamil Yang Melakukan ANC 
Received: 03 April 2021 :: Accepted: 24 April 2021 :: Published: 30 April 2021

\begin{tabular}{|c|c|c|c|}
\hline No & $\begin{array}{l}\text { Karakteristik } \\
\text { Responden }\end{array}$ & (f) & (\%) \\
\hline \multirow[t]{5}{*}{1} & Usia & & \\
\hline & Usia < 21 & 8 & 42,1 \\
\hline & Usia $21-35$ & 7 & 36,8 \\
\hline & Usia > 35 & 4 & 21,1 \\
\hline & Total & 19 & 100 \\
\hline \multirow[t]{6}{*}{2} & Pendidikan & & \\
\hline & SD & 7 & 36,8 \\
\hline & SMP & 6 & 31,6 \\
\hline & SMA & 4 & 21,1 \\
\hline & $\mathrm{S} 1$ & 2 & 10,5 \\
\hline & Total & 19 & 100 \\
\hline \multirow[t]{5}{*}{3} & Pekerjaan & & \\
\hline & IRT & 13 & 68,4 \\
\hline & Wirausaha & 4 & 21,1 \\
\hline & PNS & 2 & 10,5 \\
\hline & Total & 19 & 100 \\
\hline
\end{tabular}

Berdasarkan tabel 1 responden yang berusia $<21$ sebanyak 8 orang ibu hamil $(42,1 \%)$, usia $21-35$ sebanyak 7 orang ibu hamil $(26,3 \%)$ dan usia $>35$ sebanyak 4 orang ibu hamil $(31,6 \%)$. Berdasarkan pendidikan SD sebanyak 7 orang ibu hamil $(36,8 \%)$, SMP sebanyak 6 orang ibu hamil $(31,6 \%)$, SMA sebanyak 4 orang ibu hamil $(21,1 \%)$ dan $\mathrm{S} 1$ sebanyak 2 orang ibu hamil $(10,5 \%)$. Berdasarkan pekerjaan IRT sebanyak 13 orang ibu hamil $(68,4 \%)$, wirausaha sebanyak 4 orang ibu hamil $(21,1 \%)$ dan PNS (Pegawai Negri Sipil) sebanyak 2 orang ibu hamil $(10,5 \%)$.

Tabel 2. Rata-rata kadar hemoglobin sebelum diberikan jus kacang hijau dan madu pada ibu hamil

\begin{tabular}{ccccc}
\hline Kadar Hb & Mean & Min & Max & SD \\
\hline $\begin{array}{c}\text { Sebelum } \\
\text { intervensi }\end{array}$ & 9,41 & 81 & 10 & 0,60 \\
\hline
\end{tabular}

Berdasarkan tabel 2. Diketahui bahwa nilai rata-rata kadar hemoglobin pada ibu hamil sebelum diberiksan jus kacang hijau dan madu 9,41 gr/dl, nilai min 81 dan max 10 dengan standar deviasi 0,60.

Tabel 3. Rata-rata kadar hemoglobin sesudah diberikan jus kacang hijau dan madu pada ibu hamil

\begin{tabular}{ccccc}
\hline Kadar Hb & Mean & Min & Max & SD \\
\hline $\begin{array}{c}\text { Sesudah } \\
\text { intervensi }\end{array}$ & 10,28 & 10 & 11 & 0,56 \\
\hline
\end{tabular}

Berdasarkan tabel 3. Diketahui bahwa nilai rata-rata kadar hemoglobin pada ibu hamil sebelum diberiksan jus kacang hijau dan madu 10,28 gr/dl, nilai min 10 dan nilai max 11 dengan standar deviasi 0,56

Tabel 4. Perbedaan kadar hemoglobin sebelum dan sesudah diberikan jus kacang hijau dan madu pada ibu hamil

\begin{tabular}{lccccc}
\hline Kadar HB & Mean & SD & $\begin{array}{c}\text { Low } \\
\text { er }\end{array}$ & $\begin{array}{c}\text { Upp } \\
\text { er }\end{array}$ & $P$ \\
\cline { 1 - 3 } Sebelum & 9,41 & 0,60 & & & \\
\cline { 1 - 3 } Sesudah & 10,28 & 0,56 & 0,97 & 1,77 & 0.00
\end{tabular}

Berdasarkan tabel 4. Diketahui

bahwa nilai rata-rata sebelum intervensi 9,41 $\mathrm{gr} / \mathrm{dl}$ dan sesudah intervensi $10,28 \mathrm{gr} / \mathrm{dl}$ dengan $p$ value 0.00 .

\section{PEMBAHASAN}

\section{a. Karakteristik Responden}

Berdasarkan tabel 1 responden yang berusia $<21$ sebanyak 8 orang ibu hamil $(42,1 \%)$, usia $21-35$ sebanyak 7 orang ibu hamil $(26,3 \%)$ dan usia $>35$ sebanyak 4 orang ibu hamil $(31,6 \%)$. Berdasarkan pendidikan SD sebanyak 7 orang ibu hamil $(36,8 \%)$, SMP sebanyak 6 orang ibu hamil $(31,6 \%)$, SMA sebanyak 4 orang ibu hamil $(21,1 \%)$ dan $\mathrm{S} 1$ sebanyak 2 orang ibu hamil (10,5\%). Berdasarkan pekerjaan IRT sebanyak 13 orang ibu hamil $(68,4 \%)$, wirausaha sebanyak 4 orang ibu hamil $(21,1 \%)$ dan PNS sebanyak 2 orang ibu hamil $(10,5 \%)$.

Wanita yang memiliki usia yang masih terlalu muda, menyebabkan perkembangan organ-organ pada 
reproduksi dan fungsi fisiologisnya belum matang secara optimal. Selain itu, mental dan kejiwaannya belum matang sehingga jika seorang wanita hamil diusia muda maka dapat menyebabkan kehamilannya tidak sempurna dan sering terjadi komplikasi pada kehamilan. Ibu hamil yang termasuk umur reproduksi tidak sehat lebih banyak yang menderita anemia dibanding ibu hamil yang termasuk umur resproduksi sehat, teori ini sejalan dengan hasil penelitian bahwa ibu hamil yang mengalami anemia mayoritas usia kurang dari 21 tahun (Lamadhah, A. 2016).

Seorang wanita dengan tingkat pendidikan yang rendah juga dapat menyebabkan keterbatasan pengetahuan dalam upaya penanganan masalah gizi dan kesehatan. Pengetahuannya tentang gizi dan kesehatan sangat berpengaruh pola konsumsi pangan sehari-hari. Kekurangan zat gizi dapat menyebabkan seorang wanita yang sedang hamil menderita anemia karena suplai darah yang mengantarkan oksigen dan makanan menuju ke janin akan terhambat. Oleh karena itu pemantauan gizi ibu hamil sangatlah penting dilakukan, dari hasil penelitian mayoritas ibu hamil berpendidikan SD sehingga diperlukan cara khusus untuk penangan anemia (Waryana, 2015).

Pekerjaan ibu mayoritas adalah ibu rumah tangga (IRT), ibu yang memiliki pekerjaan diluar rumah dan memiliki pekerjaan yang baik maka akan memiliki pengetahuan yang lebih baik karena sering berinteraksi dengan orang lain, sehingga dapat berbagi pengalaman khususnya tentang anemia pada ibu hamil, dari hasil penelitian ibu hanya bekerja sebagai ibu rumah tangga.

\section{b. Perbedaan kadar Hb sebelum dan sesudah Intervensi}

Berdasarkan hasil analisa $U j i$ Paired T-Test, didapatkan hasil penelitian $\mathrm{p}$-alue $0,00<0,05$ yang artinya $\mathrm{HO}$ di tolak dan $\mathrm{Ha}$ diterima yaitu ada pengaruh sebelum dan sesudah pemberian jus kacang hijau dan madu terhadap kadar hemoglobin pada ibu hamil di Klinik Bidan Maiharti Kisaran Barat.

Hasil penelitian ini sesuai dengan penelitian Kurniasih. $D$, dkk (2018), bahwa setelah dilakukan uji statistik didapat hasil $p$ value $0,00<$ 0,05 . Maka dapat disimpulkan bahwa $\mathrm{HO}$ ditolak dan $\mathrm{Ha}$ diterima yang artinya adanya pengaruh pemberian puding kacang hijau terhadap kadar hemoglobin pada ibu hamil. Mengkonsumsi dua cangkir jus kacang hijau perhari berarti telah mengkonsumsi sebanyak 50\% kebutuhan zat besi setiap hari yaitu 18 miligram dan dapat meningkatkan kadar $\mathrm{Hb}$ kurang lebih selama 2 minggu. Hal ini dikarenakan kacang hijau mengandung zat besi sebanak 2,25 mg dalam setiap setengah cangkir kacang hijau. Kacang hijau juga mengandung fitat sebedar 2,19\%. Fitat dapat menghambat penerapan zat besi sehingga dianjurkan untuk merendam kacang hijau sebelum mengolahnya (Tarwoto \& Wasnidar, 2013).

Selain kacang hijau madu juga terbukti dapat menjadi salah satu alternatif tradisional alami untuk mencegah anemia, Madu dikenal dapat meningkatkan daya tahan tubuh selain itu kandungan gizi yang lengkap pada madu juga dapat digunakan untuk mencegah anemia. Vitamin B pada madu dan kacang hijau dapat mengatasi mual muntah yang terjadi pada ibu hamil. Madu juga dapat mengatasi sakit ternggorokan yang dirasakan oleh ibu hamil dan juga madu bermanfaat untuk melawan reaksi alergi serta mengaktifkan sistem kekebalan tubuh (Susane LMA \& 
Ristyaning $P$, 2016).

Penelitian yang dilakukan di klinik Bidan Maiharti menggunakan jus kacang hijau yang dicampur dengan madu sebagai treatmen bagi ibu hamil yang mengalami anemia ringan dan anemia sedang, dimana mereka diberikan $250 \mathrm{ml}$ jus selama 7 hari berturut-turut dnegan takaran 100 gram kacang hijau yang direndam selama 1 jam lalu direbus dengan 300 $\mathrm{ml}$ air setelah mendidih tunggu kacang hijau tersebut dingin lalu diblender setelah itu campurkan madu sebanyak 2 tbsp (43gr).

Hasil ini juga sesuai dengan penelitian Cholifah. N \& Wulandari. A (2019) diperoleh hasil bahwa ada perbedaan pemberian madu hutan terhadap kenaikan kadar HB pada kelompok intervensi sebelum dan sesudah diberikan perlakukan dengan nilai p 0,007. Sehingga disarankan kepada remaja putri yang mengalami anemia untuk dapat mengkonsumsi madu.

Hal ini membuktikan bahwa madu mengandung banyak mineral seperti natrium, kalsium, magnesium, alumunium, besi, fosfor, dan kalium, ditambah lagi kandungan vitamin yang ada didalamnya seperti B1, B2, Vitamin C, B6, niasin, asam pantotenat, biotin, asam folat dan vitamin $\mathrm{K}$. Ketika madu dikonsumsi setiap hari, penderita anemia dapat melihat peningkatan secara signifikan dalam tingkat energi, kemudian madu membantu meningkatkan penerapan kalsium, jumlah hemoglobin dan mengobati atau mencegah anemia karena faktor gizinya (Devyani, D.W, 2016).

\section{KESIMPULAN}

Dari hasil penelitian dapat disimpulkan bahwa ada pengaruh perbedaan jumlah kadar hemoglobin $\mathrm{Hb}$ ) pada ibu hamil sebelum dan sesudah diberikan jus kacang hijau dan madu di Klinik Bidan Maiharti Kisaran Barat dengan $p 0,00<0,05$. Disarankan kepada ibu hamil agar dapat mengkonsumsi jus kacang hijau dan madu karena terbukti efektif dalam meningkatkan kadar hemoglobin pada ibu hamil.

\section{DAFTAR PUSTAKA}

Amalia. A. (2016). Efektifitas Minuman Kacang Hijau Terhadap Peningkatan Kadar $\mathrm{Hb}$. Rakernas Aipkema https://jurnal.unimus.ac.id/index. php/psn12012010/article/view/20 67.

Astawan. 2009. Sehat dengan Hidangan Kacang dan Biji-Bijian. Jakarta : Penebar Swadaya

Cholifah, N \& Wulandari, A. (2019). Aplikasi Pemberian Madu terhadap Peningkatan Hemoglobin ( $\mathrm{Hb}$ ) Pada Remaja Putri yang Mengalami Anemia.

http://repository.urecol.org/index. php/proceeding/article/view/393.

Devyani, D. W. (2016). Madu Sebagai Terapi Komplementer. Yogyakarta: Graha Ilmu.

Dinas Kesehatan Provinsi Sumatera Utara. (2016). Profil Kesehatan Provinsi Sumatera Utara.

Faisal M.Sakri (2015) Madu dan Khasiatnya. Yogyakarta : Diandra Pustaka Indonesia.

Hidayat, A. (2010). Metode Penelitian Kebidanan dan Tehnik Analisis Data. Surabaya: Salemba.

Kementrian Kesehatan RI. (2017). Profil Kesehatan Indonesia. Jakarta: Kemenkes RI. http://www.depkes.go.id/resource s/download/pusdatin/profilkesehatanindonesia/ProfilKesehatan-Indonesia-tahun2017.pdf

Kurniasih, D \& dkk. (2018). Pengaruh 
Received: 03 April 2021 :: Accepted: 24 April 2021 :: Published: 30 April 2021

Puding Kacang Hijau terhadap

Kadar Hemoglobin Ibu Hamil

Dengan Anemia. Vol. 8, No 2.

http://jurnal.stikeshangtuah-

tpi.ac.id/.

Lamadhah, A. (2016). Buku Pintar Kehamilan dan Melahirkan.

Yogyakarta: Diva Press.

Manuaba,IBG. 2010. I/mu Kebidanan, Penyakit Kandungan dan KB Untuk Pendidikan Bidan Edisi 2. Jakarta

Nur Islamiyah, Dkk. (2017). Pengaruh Madu terhadap Kadar Hemoglobin Remaja Putri Kelas $X$ Yang Mengalami Anemia Di Smkn 01 Mempawah Hilir. Jurnal ProNers. jurnal.untan.ac.id

Notoatmodjo. (2012). Metodologi Penelitian Kesehatan. Jakarta: PT. Rineka Cipta.

Retnorini. D.L, Widatiningsih.S \& Masini, (2017). pengaruh pemberian tablet $F E$ dan sari kacang hijau terhadap kadar $H B$ pada ibu hamil. Jurnal Kebidanan Vol 6 No 12.

Saifuddin. (2015). Buku Acuan Nasional Pelayanan Kesehatan Maternal dan Neonatal. Jakarta : YBP-SP.

Sugianto, dkk. (2013). Riset Kesehatan Dasar ; Riskesdas dalam Angka Daerah Istimewa Yogyakarta. Jakarta : Badan Penelitian dan Pengembangan Kesehatan Kemenkes RI.

Susane LMA \& Ristyaning P. (2016). Madu sebagai Peningkat Kadar Hemoglobin pada Remaja Putri yang Mengalami Anemia Defisiensi Besi. Jurnal Majority, Vol. 5, No 1.

Tarwoto \& Wasnidar. (2013). Buku Saku Anemia pada Ibu Hamil Konsep dan Penatalaksanaan. Jakarta : Trans Info Media.

Waryana. (2015). Gizi Reproduksi. Yogyakarta: Pustaka Rihana. 